\title{
Chromitite in a Tibetan ophiolite records deep upper-mantle circulation and episodic subduction
}

\author{
SUZANNE Y. O'REILlY ${ }^{1,2^{*}}$, QING XIONG ${ }^{1,2}$, WILLIAM L. \\ GRIFFIN $^{1,2}$ HADRIEN HENRY ${ }^{1}$, JIAN-PING ZHENG ${ }^{1,2}$, \\ NORMAN J. PEARSON ${ }^{1}$ \\ ${ }^{1}$ CCFS \& GEMOC, Macquarie Univ., NSW 2109, Australia \\ (*correspondence: sue.oreilly@mq.edu.au) \\ ${ }^{2}$ GPRM, China Univ. of Geosciences, Wuhan 430074, China
}

The microstructures, major- and trace-element compositions of minerals and electron backscattered diffraction (EBSD) maps of high- and low-Cr\# [spinel $\left.\mathrm{Cr} \#=\mathrm{Cr}^{3+} /\left(\mathrm{Cr}^{3+}+\mathrm{Al}^{3+}\right)\right]$ chromitites and dunites from the Zedang ophiolite in the Yarlung Zangbo Suture (South Tibet) have been used to reveal their genesis and the related collision, subduction and exhumation geodynamic processes in the Neo-Tethyan Ocean ${ }^{[1]}$. The high-Cr\# $(0.77-0.80)$ chromitites (with or without diopside exsolution) have chromite compositions consistent with initial crystallization by interaction between picritic/boninitic magmas, harzburgite and reaction-produced magmas in a shallow, mature mantle sub-arc wedge. Some high-Cr\# chromitites show crystalplastic deformation and grain growth on previous chromite relics that have exsolved needles of diopside. These features are similar to those of the Luobusa high-Cr\# chromitites, inferred to have been recycled from the deep upper mantle (or the Mantle Transition Zone) in a mature subduction system ${ }^{[2]}$. The rapid upwelling of these deep-seated materials preserved the coexistence of ultrahigh-pressure (UHP) phases and normal-pressure spinel-facies mantle rocks.

In contrast, mineralogical, chemical and EBSD features of the Zedang low-Cr\# (0.49-0.67) chromitites and dunites and the silicate inclusions in chromite, indicate that they formed by rapid interaction between forearc basaltic magmas (MORB-like but with rare subduction input) and the Zedang harzburgites in a dynamically extended, incipient forearc lithosphere. The evidence implies that the high-Cr\# chromitites were produced or emplaced in an earlier mature arc (possibly Jurassic), while the low-Cr\# associations formed in an incipient forearc during the initiation of a new episode of Neo-Tethyan subduction at $\sim 130-120 \mathrm{Ma}$. This twoepisode subduction model can provide a new explanation for the coexistence of high- and low-Cr\# chromitites as well as of the UHP and normal phases in the same volume of ophiolitic mantle.

[1] Xiong et al. (2017) Contrib. Mineral. Petrol. 172:45.

[2] Satsukawa et al. (2015) Sci. Reports 5, 16484; doi: $10.1038 /$ srep 16484 